\title{
Effect of season on scrotal circumference, semen characteristics and testosterone serum concentration in Mexican Corriente and other beef breed bulls
}

\author{
A. Quezada-Casasola ${ }^{1,3}$, K.E. Martínez-Armendáriz ${ }^{1}$, J.M. Carrera-Chávez $^{1}$, E. Pérez-Eguía $^{1}$, \\ C.A. Rodríguez-Alarcón ${ }^{1}$, L. Avendaño-Reyes ${ }^{2}$
}

${ }^{1}$ Departamento de Ciencias Veterinarias, Universidad Autónoma de Ciudad Juárez, Ciudad Juárez, Chihuahua, México.

${ }^{2}$ Instituto de Ciencias Agrícolas, Universidad Autónoma de Baja California, Ejido Nuevo León, Baja California, México.

\begin{abstract}
To evaluate the effects of season on semen, scrotal circumference and testosterone concentration in Corriente and European-breed bulls, 758 samples were analyzed in four years. Comparisons were made between bulls of the same breed in different seasons and between bulls of different breeds in the same season. Scrotal circumference of both breeds was higher in the summer and autumn $(\mathrm{P}<0.01)$. Sperm concentration, individual motility and live cells were lower in summer and autumn in European-breed bulls $(\mathrm{P}<0.01)$. All percentages of sperm defects were higher, and testosterone was lower in European-breed bulls during summer and autumn $(\mathrm{P}<0.01)$. Gross motility tended to be lower $(\mathrm{P}=0.09)$ in European-based bulls during winter. Scrotal circumference was higher in Europeanbreed bulls than Corriente bulls in all seasons $(\mathrm{P}<0.01)$. Ejaculate volume and sperm concentration were similar in Corriente and European-breed bulls in all seasons $(\mathrm{P}>0.1)$. Individual motility was lower in Europeanbreed than in Corriente bulls in summer and autumn $(\mathrm{P}<0.01$ and $<0.01)$. Live cells count was lower in European-breed than in Corriente bulls during the summer and autumn $(\mathrm{P}<0.01$ and $<0.01)$. Major sperm defects were higher for Corriente than European-breed bulls during winter $(\mathrm{P}<0.01)$. Minor cell defects were higher in summer and autumn $(\mathrm{P}<0.01)$ in Europeanbreed than in Corriente bulls. Total defects were lower in Corriente than in European-breed bulls during summer and autumn $(\mathrm{P}<0.01)$, and higher during winter $(\mathrm{P}<0.01)$. Testosterone was higher in Corriente bulls during summer $(\mathrm{P}<0.01)$ and autumn $(\mathrm{P}<0.01)$ than in European-breed bulls. Gross motility was lower $(\mathrm{P}<0.05)$ in European-breed than in Corriente bulls in winter. Season had no effect on most semen characteristics in Corriente bulls, while European-breed bulls had lower semen quality during the hotter seasons. This indicates a better adaptation of Corriente cattle, suggesting that these bulls can be used for mating all year in hot environments.
\end{abstract}

Keywords: Corriente cattle, reproduction, seasons, semen characteristics, testosterone.

\section{Introduction}

The reproductive performance of a bull depends on many factors affecting seminal, behavioral and physiological characteristics. In general, cattle has been recognized to follow a non-seasonal reproductive pattern, meaning that bulls and cows do not breed during certain seasons of the year only, because the hypothalamic-hypophyseal-gonadal axis is considered to be insensitive to the pineal gland hormone; therefore, their gonads function throughout the year (Short, 1987). However, it is well known that in continuous breeding programs under harsh environmental conditions without nutritional supplementation, cattle breed more effectively during summer and early autumn months, when food availability is higher; moreover, cattle living in very high latitudes have been reported to breed seasonally, with most calvings occurring during spring (Borisenkov et al., 2004). Environmental factors such as temperature, rainfall and photoperiod affect the reproductive pattern in cattle, where differences can be observed among animals of different genuses, species and breeds (Lamothe-Zavaleta et al., 1991), and where better adapted animals to harsh environments may breed more efficiently throughout the seasons of the year. Such is the case of Corriente cattle, a Mexican-native biotype of cattle that has been bred in northern states of this country. These cattle are used nowadays mainly for roping activities in rodeo, due to their small size, high strength and agility (Russell et al., 2000) but have been long bred by native people in the Mexican state of Chihuahua for meat producing purposes. Currently, a large population of Criollo cattle can be located primarily in the mountainous regions of the state, under subhumid temperate weather conditions, however, in recent years, breeders have also settled in desert regions, where Criollo cattle can be found under extreme arid conditions (Rios, 2010).

The survival of these cattle has depended entirely on the availability of naturally-grown forage, without the use of any reproductive or health management, which has resulted in animals very well adapted to harsh environmental conditions that are able to live and reproduce where cattle of other breeds may not survive (Russell et al., 2000; Quezada-Casasola et al., 2014). The hypothesis in the present study is that under similar environmental and nutritional conditions, differences may exist between European-breed and Corriente bulls, in terms of testicular size, semen characteristics and testosterone concentrations throughout seasons of the year. Therefore, the objective was to evaluate the effect of the season of the year on the seminal characteristics, scrotal circumference and 
testosterone serum concentrations of Mexican Corriente and other European-breed bulls.

\section{Material and Methods}

All procedures involving animals in the present study were conducted according to approved local official techniques of animal care and health in Mexico (Federal Law of Animal Health; articles 19 to 22 and NOM-051-ZOO-1995: Humanitarian care of animals during mobilization). A total of 758 semen samples from 7 Mexican Corriente and 8 European-breed mature bulls (Angus $n=6$, Hereford $n=1$ and Limousin $n=1$ ) were analyzed during all four seasons of a four-year period (2009 to 2012). Bulls averaged 52 months of age (range 38 to 62 months) and were selected for the study considering their presence throughout the whole experimental period at the ranch of Autonomous University of Ciudad Juarez, México, which is located in the northern state of Chihuahua, Mexico ( $31^{\circ} 21^{\prime} 20^{\prime \prime}$ $\mathrm{N}, 105^{\circ} 59^{\prime} 58^{\prime \prime} \mathrm{W}$ ), in a very dry zone with extreme desert weather. The average annual temperatures range from -15 to $47^{\circ} \mathrm{C}$ with average of $18.5^{\circ} \mathrm{C}$ in spring, $27.9^{\circ} \mathrm{C}$ in summer, $18.3^{\circ} \mathrm{C}$ in autumn and $8.6^{\circ} \mathrm{C}$ in winter (Instituto Nacional de Estadística y Geografía INEGI, 2014). For experimental purposes, seasons of the year were defined as follows: spring (March 1 to May 31), summer (June 1 to August 31), autumn (September 1 to November 30) and winter (December 1 to February 28 or 29). Ambient temperature and daylight hours were registered daily at the weather station located inside the University ranch and are presented in Table 1. During the study, all bulls were housed in one of two shaded pens and were fed a diet of which consisted in a mix of alfalfa, oat and bermudagrass hay enough to maintain a body condition of 4 or 5 (in a scale from 1 to 9; Richards et al., 1986). Diet was similar in all four seasons of the year throughout the experiment and minerals and fresh water were offered ad libitum. All bulls were handled and all semen samples were obtained by electroejaculation by the same technician. Samples were obtained from each bull at least three times during each season of each year with resting periods $\geq 21$ days. Prior to ejaculation, scrotal circumference of each bull was measured at the widest point of the scrotum using a metric tape. Afterwards, the prepuce was washed with clean water and feces were removed from the rectum prior to a gentle massage of the accessory glands for $1 \mathrm{~min}$. The lubricated probe of the electroejaculator (Standard Precision Electronics, Broomfield, CO, USA) was inserted and ejaculation was achieved by gradually increasing the voltage for $2 \mathrm{~s}$, followed by a $2 \mathrm{~s}$ break until a volume $\geq 0.5 \mathrm{ml}$ of semen was obtained. Each sample was collected in a prewarmed, graded, conical plastic tube, protected from light, cold shock and abrupt temperature changes with a polystyrene cover until further analysis. Immediately following collection, ejaculate volume was measured directly in the graded collection tube and a small drop of semen from each sample was placed on a prewarmed slide and evaluated using 100X microscopy for gross motility. The presence of dark, thick, rapidly oscillating swirls indicated a sample with excellent motility, with a high percentage of sperm that were highly motile and with high cellular concentration. Such samples were classified as "very good". Samples that displayed slower moving swirls were classified as "good". Samples that did not display swirls, but showed significant individual sperm movement were classified as "fair". Samples that had very little sperm movement or no movement at all were classified as "poor". For experimental analysis, samples were classified into two categorical groups: those with very good, good and fair gross motility formed one group (acceptable motility) and those with poor gross motility formed another one (non-acceptable motility), according to the current standards set forth by the Society for Theriogenology, which indicate that bulls must have a minimum of "fair" sperm motility to be considered fertile enough (Ott, 1986). Individual sperm cell motility rate was calculated using $400 \mathrm{X}$ microscopy on a drop of semen that was previously diluted with warmed citrate sodium solution and placed on a prewarmed covered slide and counting the cells that moved progressively across the field out of a count of one hundred cells (Chenoweth et al., 1992).

Throughout the experiment, sperm concentration was measured using a spectrophotometer (Animal Reproduction Systems; Chino, CA, USA) according to the manufacturer instructions or a hemacytometer (Neubauer's chamber) cell-counting method (Muhammad et al., 2009). To evaluate sperm morphology and to determine live cells, spermatozoa were fixed on a warm slide using eosin-nigrosin stain and observed under 1000X magnification (Chenoweth et al., 1992). Stained cells in the smear were counted as dead, while unstained cells were considered as live cells. Sperm morphological alterations were classified according to Hopper (2015) into major defects (acrosome defects, proximal droplets, abnormal loose heads, abnormal contour, abnormal midpiece, vacuoles, dag defect or double forms) and minor defects (small normal heads, normal loose heads, distal droplets, abaxial implantation, coiled tails). In both traits, a total of 100 cells were evaluated per sample and the corresponding percentage was calculated accordingly.

At the time of sampling each bull, a blood sample was collected by jugular vein puncture into a 10 $\mathrm{ml}$ vacutainer tube (Fisher Scientific, Pittsburgh, PA), transported on ice immediately to the laboratory and centrifuged at $3,000 \mathrm{x}$ g for $30 \mathrm{~min}$ at $4^{\circ} \mathrm{C}$. Serum was collected in a $2 \mathrm{ml}$ microcentrifuge tube and stored at $20^{\circ} \mathrm{C}$ until radioimmunoassay analysis was performed. Serum testosterone concentration was determined by radioimmunoassay using the methodology described by Murdoch and Dunn (1982). The antibody 11-BSA\#5-50 was used in a dilution of 1:40,000 and bound 42.1 of the labeled testosterone. Sensitivity of the assay was 16.2 pg per tube and the inter and intra coefficients of variation were 12.4 and $15.1 \%$, respectively.

Data related to scrotal circumference, ejaculate volume, sperm cell concentration, individual motility, live sperm cells, testosterone concentration, as well as minor, major and total cellular defects were compared 
between different breeds (Corriente and European) in the same season of all four years of the experiment and for bulls of the same breed between different seasons of the year under a completely randomized design using the GLM procedure of SAS. Resulting means of the ANOVA were compared with Tukey tests and differences were considered as statistically significant at the $\mathrm{P} \leq 0.05$ level whereas a trend was accepted to occur if $0.05<\mathrm{P}<0.10$. Data related to gross motility of semen from both breed groups and all four seasons was compared between categorical groups with acceptable motility a non-acceptable motility with a Chi-squared or Fisher's exact test using the FREQ procedure of SAS (Statistical Analysis System, version 9.0).

\section{Results}

Mean, range and SEM values of scrotal circumference, volume of ejaculate, sperm cell concentration, individual motility, live sperm cell percentage, sperm cell defects and serum testosterone concentrations of European-breed and Corriente bulls during all season of the year are shown in Table 2 .

Comparison of bulls of the same breed between different seasons of the year

Scrotal circumference of Corriente and European-breed bulls were higher in the summer and autumn than in winter and spring $(\mathrm{P}<0.01)$. Volume of ejaculate of Corriente and European-breed bulls was similar in all four seasons of the year $(\mathrm{P}=0.53$ and 0.81 , respectively). Sperm cell concentration was similar in all seasons of the year in Corriente bulls $(\mathrm{P}=$ 0.17 ), but was lower during summer and autumn than in winter and spring in bulls of European breeds $(\mathrm{P}<$ $0.01)$. Percentage of individual motility in Corriente bulls was similar in all seasons of the year $(\mathrm{P}=0.58)$ but in European-breed bulls was lower during summer and autumn $(\mathrm{P}<0.01)$. Percentage of live sperm cells per ejaculate was similar in all four seasons of the year in Corriente $(\mathrm{P}=0.57)$ but was lower for Europeanbreed bulls during summer and autumn $(\mathrm{P}=<0.01)$. Percentage of sperm cells with major, minor and total defects in ejaculates from Corriente bulls was similar in all seasons ( $\mathrm{P}=0.22,0.36$ and 0.29 , respectively), but was higher in ejaculates from European-breed bulls during summer and autumn $(\mathrm{P}<0.01$ and $<0.01$, respectively). Serum testosterone concentration was similar in Corriente bulls in all seasons of the year $(\mathrm{P}=$ 0.19), but was lower in European-breed bulls during summer and autumn $(\mathrm{P}<0.01)$. Ejaculates from Corriente bulls had similar $(\mathrm{P}=0.11)$ acceptable gross motility rates during spring (26 out of $28,92.8 \%$ ), summer ( 54 out of $54,100 \%$ ), autumn (42 out of 42 , $100 \%$ ) and winter (46 out of 46, 100\%). Ejaculates from European-based bulls had similar acceptable gross motility rates during spring (42 out of 42, 100\%), summer $(47$ out of $50,94.0 \%)$ and autumn (72 out of $75,96.0 \%$ ), but tended to be lower during winter (37 out of $42,88.1 \% ; \mathrm{P}=0.09$ ).

Comparison of bulls of different breeds in the same season of the year

Scrotal circumference was higher in Europeanbreed bulls than Corriente bulls in spring, summer, autumn and winter $(\mathrm{P}<0.01)$. Volume of ejaculate was similar for Corriente and European-breed bulls during spring, summer, autumn and winter $(\mathrm{P}=0.43 .0 .62,0.57$ and 0.15 respectively), as well as sperm cell concentration, which was similar for Corriente and European-breed bulls during spring $(\mathrm{P}=0.45)$, summer $(\mathrm{P}=0.18)$, autumn $(\mathrm{P}=0.27)$ and winter $(\mathrm{P}=0.69)$. Percentage of individual motility was similar for both types of cattle in winter and spring $(\mathrm{P}=0.17$ and 0.90 , respectively), but it was lower for European-breed bulls during summer and autumn $(\mathrm{P}<0.01$ and $<0.01$, respectively). Percentage of live sperm cells per ejaculate was similar for Corriente and European-breed bulls in spring $(\mathrm{P}=0.77)$ and winter $(\mathrm{P}=0.92)$, but was lower for European-breed bulls during the summer and autumn ( $\mathrm{P}<0.01$ and $<0.01$, respectively). Percentage of sperm cells with major defects in the ejaculate was similar for Corriente and European-breed bulls during spring $(P=0.23)$, summer $(P=0.15)$ and autumn $(P=$ $0.11)$, however, it was higher for Corriente bulls during winter $(\mathrm{P}<0.01)$. Percentage of sperm cells with minor defects was similar for Corriente and European-breed bulls in the winter and spring $(\mathrm{P}=0.74$ and 0.21 , respectively) but was higher in summer $(\mathrm{P}<0.01)$ and autumn $(\mathrm{P}<0.01)$ for European-breed bulls. Percentage of total defects was similar for both racial groups during the spring $(\mathrm{P}=0.18)$, however, it was lower for Corriente bulls during summer $(\mathrm{P}<0.01)$ and autumn ( $\mathrm{P}$ $<0.01)$ and higher during winter $(\mathrm{P}<0.01)$. Serum testosterone concentrations was higher in Corriente bulls during summer $(\mathrm{P}<0.01)$ and autumn $(\mathrm{P}<0.01)$ but were similar to those of European-breed bulls during spring $(\mathrm{P}=0.60)$ and winter $(\mathrm{P}=0.21)$. Ejaculates from Corriente and European-breed bulls had similar acceptable gross motility rates during spring, summer and autumn ( $\mathrm{P}=0.15,0.10$ and 0.55 , respectively), but rate was lower in ejaculates from European-breed bulls during winter, when compared to those from Corriente bulls $(\mathrm{P}=0.02$; Table 3$)$. 
Table 1. Mean daylight hours and ambient temperatures per month during the years of the experimental period.

\begin{tabular}{|c|c|c|c|c|c|c|c|c|c|c|c|c|c|}
\hline \multirow{3}{*}{ Month } & \multirow{3}{*}{$\begin{array}{l}\text { Mean } \\
\text { daylight } \\
\text { hours }\end{array}$} & \multicolumn{3}{|c|}{2009} & \multicolumn{3}{|c|}{2010} & \multicolumn{3}{|c|}{2011} & \multicolumn{3}{|c|}{2012} \\
\hline & & \multicolumn{3}{|c|}{ Temperature $\left({ }^{\circ} \mathrm{C}\right)$} & \multicolumn{3}{|c|}{ Temperature $\left({ }^{\circ} \mathrm{C}\right)$} & \multicolumn{3}{|c|}{ Temperature $\left({ }^{\circ} \mathrm{C}\right)$} & \multicolumn{3}{|c|}{ Temperature $\left({ }^{\circ} \mathrm{C}\right)$} \\
\hline & & Minimum & Maximum & Mean & Minimum & Maximum & Mean & Minimum & Maximum & Mean & Minimum & Maximum & Mean \\
\hline January & $10: 23$ & -2.0 & 26.0 & 7.6 & -6.0 & 23.0 & 10.0 & -4.0 & 26.0 & 5.5 & -6.5 & 22.0 & 10.4 \\
\hline February & $11: 06$ & -2.0 & 31.0 & 10.5 & -5.0 & 26.0 & 10.9 & -15.0 & 28.0 & 6.7 & -3.0 & 24.5 & 12.3 \\
\hline March & $12: 01$ & 0.0 & 35.0 & 13.9 & 2.5 & 31.0 & 16.2 & 1.5 & 32.0 & 15.2 & 2.5 & 29.5 & 16.8 \\
\hline April & $12: 58$ & 9.5 & 36.0 & 18.5 & 7.5 & 36.0 & 21.8 & 6.0 & 35.0 & 19.0 & 7.0 & 32.5 & 22.6 \\
\hline May & $13: 46$ & 9.0 & 43.5 & 23.1 & 9.0 & 39.0 & 25.4 & 8.0 & 38.0 & 21.2 & 11.0 & 36.0 & 26.2 \\
\hline June & $14: 09$ & 21.0 & 47.0 & 27.7 & 22.0 & 45.0 & 33.8 & 18.0 & 47.0 & 31.6 & 21.5 & 44.5 & 32.5 \\
\hline July & $13: 57$ & 24.0 & 41.5 & 28.6 & 23.5 & 45.0 & 30.6 & 22.0 & 44.0 & 27.5 & 19.5 & 45.5 & 30.6 \\
\hline August & $13: 15$ & 16.0 & 42.0 & 27.5 & 20.0 & 42.5 & 31.5 & 22.0 & 45.0 & 30.6 & 23.0 & 44.0 & 32.1 \\
\hline September & $12: 20$ & 15.0 & 40.5 & 24.2 & 14.5 & 39.0 & 26.2 & 16.0 & 43.0 & 25.5 & 15.0 & 38.0 & 26.1 \\
\hline October & $11: 23$ & 3.0 & 36.5 & 18.7 & 3.0 & 38.0 & 19.3 & 4.0 & 36.0 & 17.0 & 6.5 & 32.5 & 21.6 \\
\hline November & $10: 34$ & 1.5 & 35.0 & 12.2 & -3.0 & 32.5 & 15.7 & -1.0 & 30.0 & 16.2 & 0.5 & 28.5 & 15.7 \\
\hline December & 10:09 & -6.0 & 26.5 & 7.7 & -7.0 & 22.0 & 8.6 & -6.0 & 25.0 & 6.8 & -4.0 & 22.0 & 10.4 \\
\hline
\end{tabular}


Table 2. Effect of year breed and season on seminal traits and serum testosterone concentrations in Corriente and European-breed bulls.

\begin{tabular}{|c|c|c|c|c|c|c|c|c|c|c|c|c|c|}
\hline & \multirow[b]{2}{*}{ Type } & \multicolumn{3}{|c|}{ Spring } & \multicolumn{3}{|c|}{ Summer } & \multicolumn{3}{|c|}{ Autumn } & \multicolumn{3}{|c|}{ Winter } \\
\hline & & Range & Mean & \pm SEMD & Range & Mean & \pm SEM & Range & Mean & \pm SEM & Range & Mean & \pm SEM \\
\hline & Corriente & $26-30$ & $27.1^{\mathrm{Bb}}$ & 1.4 & $23-32$ & $28.4^{\mathrm{Ab}}$ & 2.0 & $26-32$ & $28.5^{\mathrm{Ab}}$ & 1.8 & $26-30$ & $27.0^{\mathrm{Bb}}$ & 1.3 \\
\hline Scrotal circumference $(\mathrm{cm})$ & European & $34-42$ & $37.1^{\mathrm{Ba}}$ & 1.8 & $35-42$ & $38.5^{\mathrm{Aa}}$ & 2.3 & $35-42$ & $39.0^{\mathrm{Aa}}$ & 2.2 & $34-42$ & $37.4^{\mathrm{Ba}}$ & 2.1 \\
\hline \multirow[t]{2}{*}{ Volume of ejaculate (ml) } & Corriente & $1.5-3.5$ & $2.9^{\mathrm{Aa}}$ & 0.7 & $2.0-5.5$ & $3.4^{\mathrm{Aa}}$ & 0.9 & $2.0-5.5$ & $3.5^{\mathrm{Aa}}$ & 0.6 & $1.5-3.5$ & $3.2^{\mathrm{Aa}}$ & 0.6 \\
\hline & European & $0.5-15.0$ & $3.6^{\mathrm{Aa}}$ & 2.3 & $1.0-7.0$ & $3.4^{\mathrm{Aa}}$ & 1.7 & $1.0-12.0$ & $3.3^{\mathrm{Aa}}$ & 2.1 & $1.5-15.0$ & $3.7^{\mathrm{Aa}}$ & 2.3 \\
\hline \multirow{2}{*}{ Concentration $\left(\times 10^{6} / \mathrm{ml}\right)$} & Corriente & $100-2250$ & $1074.2^{\mathrm{Aa}}$ & 525.5 & $400-2364$ & $1171.5^{\mathrm{Aa}}$ & 420.9 & $568-1965$ & $1223.6^{\mathrm{Aa}}$ & 352.7 & $520-1950$ & $1048.4^{\mathrm{Aa}}$ & 364.0 \\
\hline & European & $144-2656$ & $1351.1^{\mathrm{Aa}}$ & 608.1 & $510-1890$ & $993.5^{\mathrm{Ba}}$ & 368.8 & $140-2500$ & $1087.8^{\mathrm{Ba}}$ & 572.7 & $104-2600$ & $1322.7^{\mathrm{Aa}}$ & 525.6 \\
\hline & Corriente & $56-98$ & $80.7^{\mathrm{Aa}}$ & 8.4 & $66-98$ & $82.9^{\mathrm{Aa}}$ & 9.2 & $69-96$ & $83.5^{\mathrm{Aa}}$ & 6.7 & $70-96$ & $84.9^{\mathrm{Aa}}$ & 6.0 \\
\hline Individual motility (\%) & European & $50-98$ & $83.9^{\mathrm{Aa}}$ & 9.3 & $15-91$ & $62.3^{\mathrm{Bb}}$ & 19.9 & $15-88$ & $58.4^{\mathrm{Bb}}$ & 19.5 & $51-98$ & $85.15^{\mathrm{Aa}}$ & 9.0 \\
\hline \multirow[t]{2}{*}{ Live sperm (\%) } & Corriente & $85-98$ & $92.5^{\mathrm{Aa}}$ & 3.3 & $85-99$ & $92.9^{\mathrm{Aa}}$ & 3.6 & $85-99$ & $93.7^{\mathrm{Aa}}$ & 3.6 & $85-98$ & $93.2^{\mathrm{Aa}}$ & 3.4 \\
\hline & European & $85-98$ & $92.3^{\mathrm{Aa}}$ & 3.5 & $65-90$ & $73.2^{\mathrm{Bb}}$ & 3.4 & $58-89$ & $71.4^{\mathrm{Bb}}$ & 3.7 & $85-99$ & $93.1^{\mathrm{Aa}}$ & 3.4 \\
\hline \multirow{2}{*}{ Major defects $(\%)$} & Corriente & $3-17$ & $10.1^{\mathrm{Aa}}$ & 4.2 & $4-18$ & $9.3^{\mathrm{Aa}}$ & 4.2 & $4-17$ & $9.7^{\mathrm{Aa}}$ & 4.0 & $3-20$ & $11.2^{\mathrm{Aa}}$ & 4.5 \\
\hline & European & $4-17$ & $9.0^{\mathrm{Ba}}$ & 3.6 & $4-22$ & $10.6^{\mathrm{Aa}}$ & 3.6 & $4-18$ & $11.1^{\mathrm{Aa}}$ & 3.9 & $4-17$ & $8.8^{\mathrm{Bb}}$ & 3.2 \\
\hline \multirow[t]{2}{*}{ Minor defects $(\%)$} & Corriente & $2-18$ & $9.3^{\mathrm{Aa}}$ & 4.5 & $3-18$ & $10.1^{\mathrm{Ab}}$ & 4.8 & $2-17$ & $10.8^{\mathrm{Ab}}$ & 4.3 & $1-18$ & $10.3^{\mathrm{Aa}}$ & 4.6 \\
\hline & European & $4-17$ & $9.1^{\mathrm{Ba}}$ & 3.6 & $4-23$ & $13.9^{\mathrm{Aa}}$ & 4.6 & $8-20$ & $14.6^{\mathrm{Aa}}$ & 2.9 & $4-19$ & $9.4^{\mathrm{Ba}}$ & 3.5 \\
\hline \multirow[t]{2}{*}{ Total defects $(\%)$} & Corriente & $10-33$ & $19.5^{\mathrm{Aa}}$ & 6.0 & $9-26$ & $19.4^{\mathrm{Ab}}$ & 6.7 & $11-33$ & $20.6^{\mathrm{Ab}}$ & 5.4 & $6-33$ & $21.6^{\mathrm{Aa}}$ & 6.3 \\
\hline & European & $10-28$ & $18.1^{\mathrm{Ba}}$ & 4.2 & $11-41$ & $24.5^{\mathrm{Aa}}$ & 6.6 & $13-38$ & $25.7^{\mathrm{Aa}}$ & 5.4 & $10-28$ & $18.2^{\mathrm{Bb}}$ & 4.5 \\
\hline \multirow{2}{*}{ Testosterone (ng/ml) } & Corriente & $2.6-5.6$ & $4.1^{\mathrm{Aa}}$ & 0.7 & $2.0-5.5$ & $3.9^{\mathrm{Aa}}$ & 1.0 & $2.4-5.2$ & $3.8^{\mathrm{Aa}}$ & 0.7 & $2.5-5.6$ & $4.0^{\mathrm{Aa}}$ & 0.8 \\
\hline & European & $1.5-6.8$ & $4.1^{\mathrm{Aa}}$ & 1.16 & $1.0-5.0$ & $2.8^{\mathrm{Bb}}$ & 0.81 & $1.0-4.5$ & $3.1^{\mathrm{Bb}}$ & 0.77 & $1.5-6.2$ & $4.3^{\mathrm{Aa}}$ & 0.9 \\
\hline
\end{tabular}

${ }_{\mathrm{A}, \mathrm{B}, \mathrm{a}, \mathrm{b}}$ Significant differences $(\mathrm{P}<0.05)$ are indicated between columns by capital letters and between rows by small letters. 
Table 3. Acceptable gross motility rates in ejaculates from Corriente and European-breed bulls throughout the seasons of the year.

\begin{tabular}{lcccc}
\hline & Spring & Summer & Autumn & Winter \\
Corriente & $26 / 28(92.8 \%)^{\mathrm{a}}$ & $55 / 55(100 \%)^{\mathrm{a}}$ & $42 / 42(100 \%)^{\mathrm{a}}$ & $46 / 46(100 \%)^{\mathrm{a}}$ \\
European & $42 / 42(100 \%)^{\mathrm{a}}$ & $47 / 50(94.0 \%)^{\mathrm{a}}$ & $72 / 75(96.0 \%)^{\mathrm{a}}$ & $37 / 42(88.1 \%)^{\mathrm{b}}$ \\
\hline
\end{tabular}

${ }^{\mathrm{a}, \mathrm{b}}$ Different letters between rows indicate significant difference $(\mathrm{P}<0.05)$.

\section{Discussion}

The smaller scrotal circumference of Corriente bulls at all seasons of the year, when compared to bulls of the others breeds, brings to attention the fact that Corrientes do not meet the criteria of the American Society of Theriogenologists. These criteria indicate that bulls should have a minimum scrotal circumference of $30 \mathrm{~cm}$ in order to be considered as mature, regardless of the breed (Hopkins and Spitzer, 1997). On this regard, it has been reported that testis size continues to increase after puberty, so the scrotal circumference of bulls that are $\geq 2$ years old should exceed $33 \mathrm{~cm}$ (Coulter, 1991; Hopkins and Spitzer, 1997), which agrees with the results of European-breed bulls of the present experiment. However, changes in testis size after 2 years of age are reported to be breed-dependant; for example, testicular growth continues beyond 2 years in Angus bulls, but not in Hereford bulls (Chenoweth et al., 1984), which may be the case of Corriente bulls, as a specific characteristic of this breed. The seasonal variation of scrotal circumference during the present experiment may indicate that Corriente bulls, although they are a breed that is well adapted to climatic conditions of the state, may be more sensitive to cold temperature. Findings of the present study agree with those of other authors which report that Brahman bulls do not maintain their scrotal circumference and testicular volume during winter and spring in North America (Godfrey et al., 1990), which leads to lower sperm cell production. Corriente bulls did not show seasonal variations in terms of sperm cell concentration. This indicates that although scrotal circumference was lower during winter and spring, the amount of sperm cells produced was not affected. European-breed bulls in the study, seemed to be more sensitive to heat stress and showed significantly lower sperm cell concentration during summer and autumn, when the mean ambient temperature reached an average of $30^{\circ} \mathrm{C}$. The negative effect of heat stress on spermatogenesis has been widely documented (Meyerhoeffer et al., 1985; Menegassi et al., 2016), and there are reports that mention that although ejaculate volume is not negatively affected by hyperthermia, initial motility, sperm concentration and total sperm counts decrease following exposure to temperatures above $29^{\circ} \mathrm{C}$ and spermatogenesis is impaired at temperatures above $30^{\circ} \mathrm{C}$ (Hansen, 2009). It is important to notice that semen characteristics are not immediately affected by high temperatures, and they do not return to normal until up to eight weeks following the end of heat stress (Hansen, 2009), which helps to explain the results of the lower sperm cell concentration found in European-breed bulls in the present study during the months of autumn that do not represent heat stress for the animals.

Volume of ejaculate was similar in both racial groups during all seasons of the year and these values agree with the ranges obtained by other authors in Bos indicus and Bos taurus bulls (Brito et al., 2002; Koivisto et al., 2009). It has been reported that seasonal effects can be observed in volume of ejaculate of bulls by a combined effect of high temperatures and poor grazing quality in the dry and hot season (Koivisto et al., 2009). Such was not the case of the animals in the present study, since all bulls were fed adequately. On the other hand, it has been demonstrated that the ejaculate volume, but not the sperm concentration and motility, is significantly influenced by the semen collection team and the ejaculator device used (Mathevon et al., 1998). Through the present study, collection conditions were standardized and semen was collected by the same technician with the same equipment in such way that the procedure was carried out similarly every time.

The lower percentages of progressively motile spermatozoa observed in samples of European-breed bulls during the summer and autumn agree with the report of Koivisto et al. (2009), who found that Limousin and Simmental bulls had lower motility values during these seasons of the year, when compared with Nelore (Bos indicus) bulls, and that the highest individual motility values were found in winter in both genotypes. Other authors describe similar results (Silva et al., 1991), indicating a better heat resistance of Bos indicus, in a similar way of Corriente cattle. The shift between the period of high temperatures and low sperm motility from the beginning of low sperm motility may reflect the time span from the beginning of heat to the appearance of heat related semen alterations, such as diminished motility, coinciding with the duration of spermatogenesis of about 2 months in bulls (Barth and Oko, 1989). This corresponds also with the return of normal motility values after exposure to heat, as reported by Meyerhoeffer et al. (1985). Although cell sperm motility is greatly related to semen quality and further conception rates (Pangewar and Sharma, 1989; Gotschall and Mattos, 1997), results from other studies (Fitzpatrick et al., 2002; Holroyd et al., 2002) indicate that it is not.

The percentage of live sperm cells is a good indicator of semen quality and is affected by high ambient temperature. It has been reported that differences exist between seasons of the year, with the lowest live sperm cell percentages occurring in summer and the highest in winter (Mathevon et al., 1998; Kebede et al., 2007). The lower percentage of live sperm observed in bulls of European breeds of the present study agrees with these findings, and it may be 
that these bulls are more susceptible to high ambient temperatures than Corriente bulls. Coincidentally, it has also been reported that cattle that has been adapted over the years to harsh environments and hot weather, such as Brazilian Curraleiro, which tends to have higher live sperm values in all seasons of the year (Teixeira et al., 2011) when compared to bulls of other breeds.

The presence of major sperm cell defects indicate disturbed spermatogenesis (Koivisto et al., 2009), therefore, the similar percentage of this kind of abnormalities in Corriente and European-breed bulls during spring, summer and autumn indicate that spermatogenesis was not affected by environmental heat. However, the percentage of minor cell defects representing changes in the epididymal sperm maturation was the highest during summer and autumn in Europeanbreed bulls. Consequently, the total percentage of sperm cell defects was also higher during summer and autumn in these bulls. These findings are in agreement with previous reports (Koivisto et al., 2009) and emphasize the better adaptation of some bulls to hot environmental conditions, such as Corriente bulls in the present study. The greater resistance in Corriente bulls than breeds of European origin to high ambient temperatures affecting sperm morphology may be explained by the specific adaptations of features enhancing the local cooling system of the testis, similar to those reported by Brito et al. (2004) in Bos indicus cattle.

Testosterone range and mean serum concentrations observed in Corriente and Europeanbreed bulls are similar to those reported by other authors (Henney et al., 1990). Concentration of testosterone has been found not to be influenced by season of the year in Holstein bulls (Peirce et al., 1987). On this regard, some authors report higher mean concentrations of testosterone during colder seasons of the year (Gwazdauskas et al., 1980), however, greater serum testosterone concentrations in June and August were observed by Stumpf et al. (1993). Results of the present study do not support these data, as mean concentrations of testosterone were greatest during winter and spring in European-breed bulls and were similar during all seasons in Corriente bulls. Discrepancies in the effect of season of the year on serum concentrations of testosterone may be due to the various experimental procedures utilized. For example, Gwazdauskas et al. (1980) collected blood from each bull every 6 weeks and Stumpf et al. (1993) did it at 10 min intervals for 24 $\mathrm{h}$. The irregular and pulsatile pattern of testosterone secretion creates problems to determine its relationship with season of the year, since samples collected at low frequency (e. g. daily) have a random chance of being collected during periods of basal secretion (Parkinson, 2004). The consequent variability of testosterone concentrations in a low-frequency sampling regime makes difficult to find association with parameters such as environmental conditions. Nevertheless, data obtained in the present study suggest that Corriente bulls may be better adapted to heat environmental conditions, being more able to maintain a stable pattern of secretion of testosterone throughout the seasons of the year than other European-breed bulls.
Season of the year had no significant effect on most of fresh semen characteristics in Corriente bulls, when compared to bulls of other European breeds in the desert conditions of northern Mexico. In general, European-breed bulls had lower semen quality during summer and autumn, the hotter seasons of the year. This shows a better adaptation of Corrientes to the hot environmental conditions of this region and suggests that this biotype of cattle can be used for mating throughout the year.

\section{References}

Barth AD, Oko RJ. 1989. Abnormal Morphology of Bovine Spermatozoa. Ames, IA: Iowa State University Press. 285 pp.

Borisenkov MF, Kalinin AI, Vakhnina NA. 2004. Seasonal dynamics of cattle reproduction in the North. Russ J Ecol, 35:205-208.

Brito LFC, Silva AEDF, Rodrigues LH, Vieira FV, Deragon LAG, Kastelic JP. 2002. Effects of environmental factors, age and genotype on sperm production and semen quality in Bos indicus and Bos taurus AI bulls in Brazil. Anim Reprod Sci, 70:181-190.

Brito LFC, Silva AEDF, Barbosa RT, Kastelic JP. 2004. Testicular thermoregulation in Bos indicus, crossbred and Bos taurus bulls: relationship with scrotal, testicular vascular cone and testicular morphology, and effects on semen quality and sperm. Theriogenology, 61:511-528.

Chenoweth PJ, Farin PW, Mateos ER, Rupp GP, Pexton JE. 1984. Breeding soundness and sex drive by breed and age in beef bulls used for natural mating. Theriogenology, 22:341-349.

Chenoweth PJ, Spitzer J, Hopkins F. 1992. A new breeding soundness evaluation form. In: Proceedings of the Annual Meeting of the Society for Theriogenology, 1992, San Antonio, TX. Pike Road, AL: Society for Theriogenology. pp. 63-70.

Coulter GH. 1991. Scrotal circumference - a review. In: Proceedings of the Society for Theriogenology, 1991, Nashville, TN. Pike Road, AL: Society for Theriogenology. pp. 113-116.

Fitzpatrick LA, Fordyce G, McGowan MR, Bertram JD, Doogan VJ, Faveri J, Miller RG, Holroyd RG. 2002. Bull selection and use in northern Australia. Part 2. Semen traits. Anim Reprod Sci, 71:39-49.

Godfrey RW, Lunstra DD, Jenkins TG, Berardinelli JG, Neudendorff DA, Long CR, Randel RD. 1990. Effect of location and season on body and testicular growth in Brahman and Hereford bulls. J Anim Sci, 68:1520-1529.

Gotschall GS, Mattos RC. 1997. Findings of andrological examinations of Bos taurus and Bos indicus bulls. Rev Bras Reprod Anim, 21:25-28.

Gwazdauskas FC, Bame JA, Aalseth DL, Vinxon WE, Saacke RG, Marshall CE. 1980. Relationship of plasma hormones and semen quality in bulls. In: Proceedings of the 8th Technical Conference on Artificial Insemination and Reproduction, 1980, Madison, WS. Columbia, MO: National Association of Animal Breeders. pp. 13-20. 
Hansen PJ. 2009. Effects of heat stress on mammalian reproduction. Philos Trans $R$ Soc Lond B Biol Sci, 364:3341-3350.

Henney SR, Killian GJ, Deaver DR. 1990. Libido, hormone concentrations in blood plasma and semen characteristics in Holstein bulls. J Anim Sci, 68:27842792.

Holroyd RG, Doogan VJ, Faveri J de Fordyce G, McGowan MR, Bertram JD, Vankan DM, Fitzpatrick LA, Jayawardhana GA, Miller RG. 2002. Bull selection and use in northern Australia. 4. Calf output and predictors of fertility of bulls in multiple-sire herds. Anim Reprod Sci, 71:67-79.

Hopkins FM, Spitzer JC. 1997. The new Society for Theriogenology breeding soundness evaluation system. Vet Clin N Am Food Anim Pract, 13:283-293.

Hopper RM. 2015. Bovine Reproduction. . Oxford, UK: Wiley Blackwell. 816 pp.

Instituto Nacional de Estadística y Geografía (México). 2014. Anuario Estadístico y Geográfico de Chihuahua. México, DF: INEGI. 521 pp.

Kebede M, Greyling JPC, Schwalbach LMJ. 2007. Effect of season and supplementation on percentage live sperm and sperm abnormalities in Horro (Zebu) bulls in sub-humid environment in Ethiopia. Trop Anim Health Prod, 39:149-154.

Koivisto MB, Costa MTA, Perri SHV, Vicente WRR. 2009. The effect of season on semen characteristics and freezability in Bos indicus and Bos taurus bulls in the souhteastern region of Brazil. Reprod Domest Anim, 44:587-592.

Lamothe-Zavaleta C, Fredriksson G, Kindahl $\mathbf{H}$. 1991. Reproductive performance of zebu cattle in Mexico 1. Sexual behaviour and seasonal influence on estrous cyclicity. Theriogenology, 36:887-896.

Mathevon M, Buhr M, Dekkers, JCM. 1998 Environmental, management and genetic factors affecting semen production in Holstein bulls. J Dairy Sci, 81:3321-3330.

Menegassi SR, Pereira GR, Bremm C, Koetz C Jr, Lopes FG, Fiorentini EC, McManus C, Dias EA, Rocha MK, Lopes RB, Barcellos JO. 2016. Effects of ambient air temperature, humidity, and wind speed on seminal traits in Braford and Nellore bulls at the Brazilian Pantanal. Int J Biometeorol, pp. 1-8. Available on: http://link.springer.com/article/10.1007\% 2Fs00484-016-1167-2. Accessed on: June 12th 2016.

Meyerhoeffer DC, Wettemann RP, Coleman SW, Wells ME. 1985. Reproductive criteria of beef bulls during and after exposure to increased ambient temperature. J Anim Sci, 60:352-357.

Muhammad A, Kroetsch T, Buhr MM. 2009. Comparison of different methods for assessment of sperm concentration and membrane integrity with bull semen. J Androl, 30:661-668.

Murdoch WJ, Dunn TG. 1982. Alterations in follicular steroid hormones during the preovulatory period in the ewe. Biol Reprod, 27:300-307.

Ott R. 1986. Breeding soundness examination in bulls. In: Morrow AD (Ed.). Current Therapy in Theriogenology. 2nd ed. Philadelphia, PA: Saunders. pp. 125-136.

Pangewar GR, Sharma RD. 1989. Physical and biochemical characteristics of semen in relation to fertility of Holstein-Freisian bulls. Indian Vet J, 13:2126.

Parkinson TJ. 2004. Evaluation of fertility and infertility in natural service bulls. Vet J, 168:215-229.

Peirce ARJ, Downey BR, Sanford LM. 1987. Seasonal changes in plasma concentrations of prolactin, LH, FSH and testosterone in young adult bulls. Anim Reprod Sci, 13:165-176.

Quezada-Casasola A, Avendaño-Reyes L, RamírezGodínez JA, Macías-Cruz U, Correa-Calderón A. 2014. Behavioural, follicular and hormonal characteristics of the oestrous cycle of Mexican Criollo cattle. Anim Prod Sci, 54:277-284.

Richards MW, Spitzer JC, Warner MB. 1986. Effect of varying levels of postpartum nutrition and body condition at calving on subsequent reproductive performance in beef cattle. J Anim Sci, 62:300-306.

Rios JG. 2010. Curso de Acreditación de Inspectores de Ganado Criollo para Registro. Chihuahua, México: Sagarpa, Asocriollo, Conargen.

Russell ND, Rios J, Erosa J, Remmenga MD, Hawkins DE. 2000. Genetic differentiation among geographically isolated populations of Criollo cattle and their divergence from other Bos taurus breeds. J Anim Sci, 78:2314-2322.

Short RV. 1987. Oestrus and menstrual cycles. In: Austin CR, Short RV (Ed.). Hormonal Control of Reproduction. 3rd ed. Cambridge, UK: Cambridge University Press. pp 145-192.

Silva AEDF, Dode MA, Porto JA, Abreu UGP. 1991. Estacionalidade na atividade sexual de machos bovinos Nelore e mestiços Fleckvieh x Nelore e Chianina x Nelore. Pesq Agropec Bras, 26:1751-1760.

Stumpf TT, Wolfe MW, Roberson MS, Kittok RJ, Kinder JE. 1993. Season of the year influences concentration and pattern of gonadotropins and testosterone in circulation of the bovine male. Biol Reprod, 49:1089-1095.

Teixeira HCA, Nascimento NV, McManus C, Egito AA, Mariante AS, Ramos AF. 2011. Seasonal influence on semen traits and freezability from locally adapted Curraleiro bulls. Anim Reprod Sci, 125:56-61. 